\title{
Proteome analyses of human macrophages exposed to low cytotoxic IC90 copper $(2+)$ ions
}

\author{
Masayuki TAIRA ${ }^{1}$, Yu SHIMOYAMA², Tadayoshi KAGIYA³ ${ }^{3}$ Minoru SASAKI², Takashi NEZU1 ${ }^{1}$, Hidemitsu HARADA ${ }^{4}$ \\ and Shigenobu KIMURA ${ }^{2}$
}

\begin{abstract}
${ }^{1}$ Division of Dental Bio-engineering, Department of Pathogenesis and Control of Oral Diseases, Iwate Medical University School of Dentistry, 1-3-27 Chuo-dori, Morioka 020-8505, Japan

${ }^{2}$ Division of Oral Microbiology and Immunology, Department of Pathogenesis and Control of Oral Diseases, Iwate Medical University School of Dentistry, 1-3-27 Chuo-dori, Morioka 020-8505, Japan

${ }^{3}$ Division of Oral Anatomy, Department of Oral Biology, Iwate Medical University School of Dentistry, 1-3-27 Chuo-dori, Morioka 020-8505, Japan ${ }^{4}$ Division of Oral Histology and Developmental Biology, Department of Oral Structure and Function Biology, Iwate Medical University School of Dentistry, 1-3-27 Chuo-dori, Morioka 020-8505, Japan

Corresponding author, Masayuki TAIRA; E-mail: mtaira@iwate-med.ac.jp
\end{abstract}

\begin{abstract}
Dental noble alloys often contain copper $(\mathrm{Cu})$. Eluted metal ions sometimes irritate oral tissues. The most eluted ions are Cu ions. The purpose of this study was to investigate the effects of low cytotoxic (IC90, $100 \mu \mathrm{mol} / \mathrm{L}$ ) Cu ions on macrophages by proteome analyses consisting of two-dimensional (2D) electrophoresis and matrix-assisted laser desorption/ionization - time of flight (MALDI-TOF) mass spectrometry. The analyses revealed that stimulation with IC90 $\mathrm{Cu}$ ions for 1 day caused the macrophage to significantly increase five specific protein spots. Mascot peptide mass finger-print matching suggested that four of them were attributed to $70 \mathrm{kDa}$ heat shock protein 1A/1B (HSP70). HSP70 expression was verified by expressions of corresponding HSPA1A and HSPA1B mRNAs of the macrophage in quantitative real-time PCR analyses. It was concluded that by producing abundant HSP70, the macrophage protected itself against intracellularly intruding cytotoxic $\mathrm{Cu}$ ions that might un-fold and crosslink cellular proteins.
\end{abstract}

Keywords: Macrophage, Proteome analysis, Copper ions

\section{INTRODUCTION}

Dental noble alloys often contain $\mathrm{Cu}^{1)} \cdot \mathrm{Cu}(2+)$ ions are most eluted from these noble dental alloys when exposed to hostile environments such as lactic acid ${ }^{2}$ secreted by oral micro-organisms and electrical polarization between two different alloys ${ }^{3}$. The quantities of $\mathrm{Cu}(2+)$ ions might be very minute ${ }^{4)}$, but their effects on oral tissues have not been well examined ${ }^{5}$. It is also known that macrophages play a key role in the body's self defense reaction against $\mathrm{Cu}(2+)$ ions and $\mathrm{Cu}(2+)$ ion-bound proteins ${ }^{6}$. Although there are many reports to evaluate cytotoxic effects of high dose $\mathrm{Cu}(2+)$ ions on fibroblasts and monocytes ${ }^{7}$, those of low-quantity $\mathrm{Cu}(2+)$ ions on macrophage are sparse ${ }^{8}$.

$\mathrm{Cu}$ has both advantageous and disadvantageous effects on the human body, dependent upon the quantities of $\mathrm{Cu}(2+)$ ions ${ }^{9)}$. Trace amounts of $\mathrm{Cu}(2+)$ ions (usually, $24 \mathrm{nmol} / \mathrm{L}$ in human serum ${ }^{10}$ ) are required to maintain human life such as for synthesis of super-oxide dismutase, the detoxification enzyme of active oxygen ${ }^{9}$. On the other hand, excess amounts of $\mathrm{Cu}(2+)$ ions, however, produce free radicals dose-dependently, damaging cell membranes and DNA, and leading to cell death ${ }^{11,12)}$. It has been further reported that $\mathrm{Cu}(2+)$ ions might cause allergies in certain circumstances ${ }^{13)}$.

The proteome analysis (i.e. 2D electrophoresis+ MALDI-TOF mass spectrometry) is relatively a new

Color figures can be viewed in the online issue, which is available at J-STAGE.

Received Jun 4, 2010: Accepted Dec 7, 2010

doi:10.4012/dmj.2010-088 JOI JST.JSTAGE/dmj/2010-088 sophisticated technique to evaluate biological phenomenon of cells at the protein expression levels ${ }^{14}$. This technology has not been, however, well used in the cytotoxicity evaluation of metallic ions, yet.

The purpose of this study was, therefore, to compare and analyze protein expressions by human macrophage [phorbol-12-myristate-13-acetate (PMA)-differentiated THP1 cells ${ }^{15}$ ] cultured for a day in two culture media, i.e.; a control medium without $\mathrm{Cu}(2+)$ ions and a test medium supplemented with low-cytotoxic (IC90) $\mathrm{Cu}(2+)$ ions by proteome analyses so that the effects of IC90 Cu (2+) ions on human macrophage could be better understood. To confirm specifically up-regulated protein expressions of the macrophage when subject to IC90 $\mathrm{Cu}$ $(2+)$ ions, expressions of corresponding mRNAs of the macrophage were further examined by quantitative real-time RT-PCR analyses ${ }^{16)}$.

\section{MATERIALS AND METHODS}

Preparation of culture media with $\mathrm{Cu}(2+)$ ions

Copper (II) chloride dihydrate (min. 99\% pure) (Jyunsei Chemical, Tokyo, Japan) was dissolved in super-pure water at the concentration of $0.2 \mathrm{~mol} / \mathrm{L}(\mathrm{Cu}(2+)$ ion stock solution, $\mathrm{pH}=3)$. It was sterilized by $0.22 \mu \mathrm{m}$ membrane filtration. By diluting this stock solution, media containing $\mathrm{Cu}(2+)$ ions with concentrations of $0,20,50$, $100,200,500$ and $1,000 \mu \mathrm{mol} / \mathrm{L}$ were prepared. The $\mathrm{pH}$ of all fresh media was maintained at around 7.2. 


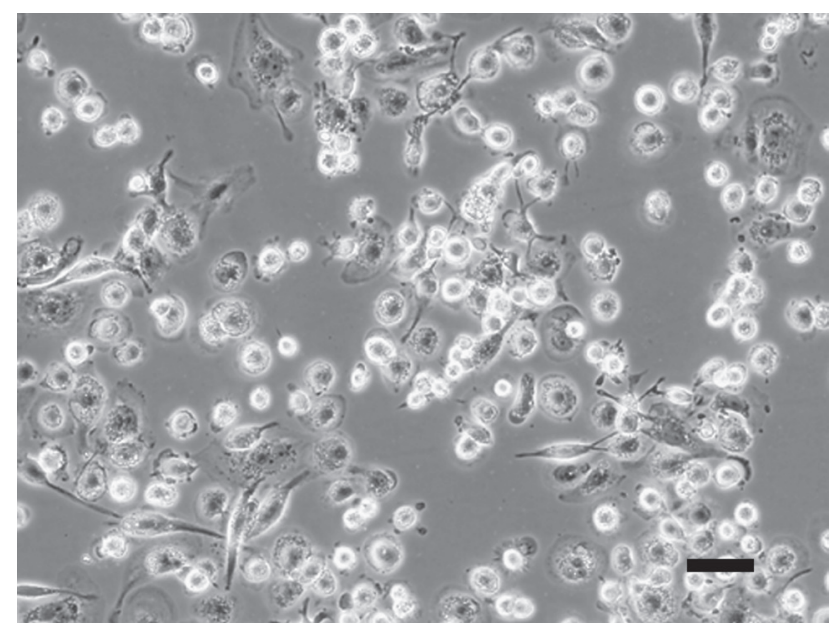

Fig. 1 The cell morphology of macrophages (PMAdifferentiated THP-1 cells). Bar size $=100 \mu \mathrm{m}$.

Cell differentiation of monocytic THP-1 to macrophage Human monocytic cell line THP-1 (RCB 1189, Riken Cell Bank, Tsukuba, Japan) was cultured in RPMI1640 medium (Invitrogen, Carlsbad, CA, USA.) supplemented with 10 vol.\% fetal bovine serum (Cat. No. 10099-141, Invitrogen, Carlsbad, CA, USA) and 2 vol.\% antibiotics (penicillin-streptomycin-amphotericin, Cat. No. 15240096, Invitrogen, Carlsbad, CA, USA.) in a $5 \% \mathrm{CO}_{2}$ incubator at $37^{\circ} \mathrm{C}$. THP-1 cells were differentiated into macrophages by culturing for $48 \mathrm{~h}$ in medium supplemented with 200 nM PMA (Sigma-Aldrich Japan, Tokyo, Japan) with a cell density of $10^{5}$ cells $/ \mathrm{mL}$. By PMA-differentiation, cells adhered on culture dishes. The cell morphology of the macrophages (PMAdifferentiated THP-1 cells) is shown in Fig. 1.

\section{Cell viability tests}

After PMA-differentiation, media $(1 \mathrm{~mL})$ were removed from each well in 24-well microplates containing adhered cells $\left(10^{5}\right)$, and fresh media without PMA but with $\mathrm{Cu}$ (2+) ions of varying concentrations from 0 to $1,000 \mu \mathrm{mol} / \mathrm{L}$ (1 $\mathrm{mL})$ were added to each well and cultured for an additional $24 \mathrm{~h}$. Cell viabilities of control macrophages and those exposed to $\mathrm{Cu}(2+)$ ions were evaluated $(n=6 ; 3$ wells for each $\mathrm{Cu}(2+)$ concentration $\times$ two repetitions of colorimetric assay) using Cell Counting Kit-8 (Doujin Chemical, Kumamoto, Japan) and a micro-plate reader (model 680, Biorad, Hercules, CA, USA.).

When cultured in IC90 concentration of $\mathrm{Cu}(2+)$ ions, the cell viability of macrophage drops to $90 \%$ relative to that of control macrophage (100\%). The IC90 $\mathrm{Cu}(2+)$ concentration was regarded as low-cytotoxic to the macrophage examined in this study.

\section{Proteome analyses}

After PMA-differentiation, media $(10 \mathrm{~mL})$ were removed from two $100 \mathrm{~mL}$ culture dishes containing adhered cells $\left(10^{6}\right)$. Control medium without PMA and $\mathrm{Cu}(2+)$ ions and fresh test medium without PMA but with IC90 Cu
$(2+)$ ions were then added to the dishes, respectively, and cultured for an additional $24 \mathrm{~h}$. After washing twice with cold PBS (-) solutions, macrophages were collected with plastic cell scrapers and centrifugation. The proteome analyses in this study consisted of the following $2 \mathrm{D}$-PAGE and mass spectrometry.

\section{D-PAGE}

Proteins (cell pellets) $(125 \mu \mathrm{g})$ were dissolved in a 8 -M urea buffer (7.8 M urea, $0.2 \mathrm{M}$ thiourea, 1.9\% Nonidet P40, 0.1 M dithiothreitol, and 0.01\% bromophenol blue) containing $0.5 \%$ pharmalyte (pH3-9) (GE Healthcare Bio-Science, Piscataway, NJ, USA) and a proteaseinhibitor cocktail (Sigma-Aldrich Co., Irvine, UK). Samples were electrically focused using an Immobiline DryStrip pH 3-10 NL and IPGphore (GE Health Bio-Science, Piscataway, NJ, USA) at $50 \mu \mathrm{A}$ per strip for $3 \mathrm{~h}$ at $20^{\circ} \mathrm{C}$. For the second dimension, the strips were equilibrated in a 6 -M urea buffer $(50 \mathrm{mM}$ Tris- $\mathrm{HCl}, \mathrm{pH}$ 6.8, $6 \mathrm{M}$ urea, 3\% SDS, $50 \mathrm{mM}$ dithiothreitol, and 0.01\% bromophenol blue) and separated on $11 \%(\mathrm{w} / \mathrm{v})$ polyacrylamide gels. The gels were then stained with Coomassie Brilliant Blue (CBB), and spots in gels were photographed by a digital camera. Quantitative analyses of protein spots were carried out with PDQuest (Biorad, Hercules, CA, USA.). To ensure reproducibility, every sample was analyzed in duplicate.

\section{Mass spectrometry}

Identifications of proteins separated on 2D-PAGE were performed by mass spectrometry as reported previously ${ }^{17)}$. Briefly, protein spots were excised and reduced. Following alkylation, in-gel digestion was performed with sequential-grade trypsin (Promega, Madison, WI, USA) overnight at $37^{\circ} \mathrm{C}$. Peptides were extracted with $50 \%(\mathrm{v} / \mathrm{v})$ acetonitrile containing $5 \%(\mathrm{v} / \mathrm{v})$ trifluoroacetic acid, and then the extract was concentrated using a Speed Vac (Thermo Fisher Scientific, Waltham, MA, USA). Mass spectra were recorded on a Voyager DE-Pro MALDI-TOF mass spectrometer (Applied Biosystems, Branchburg, NJ, USA). Matrix-related ions ( $\alpha$-cyano-4hydroxycinnamic acid (Applied Biosystems Co., Foster City, CA, USA) (CHCA)) and trypsin autolysis products were used for internal calibration. Peptide mass fingerprinting analysis was performed using Mascot Search available at http://www.matrixscience.com (Matrix Science, Boston, MA, USA.). The conditions for search analyses were as follows: Database=SwissProt. 2010_008; Taxonomy=Homo Sapiens; Enzyme=Trypsin; Mass values=Monoisotropic; Protein Mass=Unrestricted; Peptide Mass Tolerance $= \pm 1.2 \mathrm{Da}$; Peptide Charge State $=1+;$ Max Missed Cleavages=1. Mascot Search results provided tables of several protein candidates which might match mass spectra of the searched spot with protein names, entry name and expectation values. Expectation value is the number of matches with equal or better scores that are expected to occur by chance alone. For a score that is exactly on the significance threshold $(p<0.05)$, the expectation value is also 0.05 . The lower the expectation value, the more significant the 
score. In this study, the protein candidate of the highest possibility was presented for each protein spot.

\section{Quantitative real-time PCR}

Total RNAs were collected from two macrophages, i.e; control and that subject to medium with IC90 Cu (2+) for 24 h, using RNeasy Plus Mini Kit (Qiagen, Valencia, CA, USA). The expressions of two genes (HSPA1A and HSPA1B) and one house-keeping gene (GAPDH) were confirmed by quantitative real-time PCR. PCR amplification of cDNA was performed by SYBR Premix ExTaq (Takara Bio, Tokyo, Japan). The primers for the real-time PCR were GGATAACGGCTAGCCTGAGGAG (the forward primer for HSPA1A gene); CTGGGAAGCCTTTGGGACAAC (the reverse primer for HSPA1A gene); TGGACTGTTGGGACTCAAGGAC (the forward primer for HSPA1B gene); GGGAACGAAACACCCTTACAGTATC (the reverse primerforHSPA1Bgene);GCACCGTCAAGGCTGAGAAC (the forward primer for GAPDH); and TGGTGAAGACGCCAGTGGA (the reverse primer for GAPDH gene). After an initial denaturation at $95^{\circ} \mathrm{C}$ for $30 \mathrm{sec}$, a two-step cycle procedure was used (denaturation at $95^{\circ} \mathrm{C}$ for $5 \mathrm{sec}$, annealing and extension at $60^{\circ} \mathrm{C}$ for 30 sec) for 40 cycles in a Dice Real Time System TP800 (Takara Bio, Tokyo, Japan). Gene expression levels were normalized according to the level of GAPDH expression. Relative amounts (RQ values) of HSPA1A and HSPA1B mRNAs in each sample were calculated by $\Delta \Delta \mathrm{Ct}$ method $(n=4 ; 2$ culture sets $\times 2$ measurement repetition for each primer set). Data were presented as means \pm standard deviation.

\section{Statistics}

Statistical analysis was performed by unpaired $t$-test.

$\mathrm{kDa}$

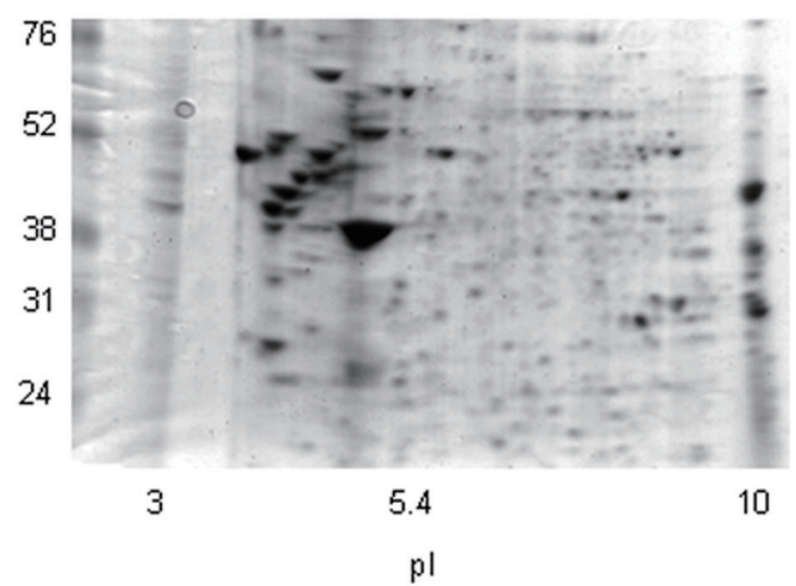

\section{RESULTS}

\section{Cell viabilities}

Fig. 2 shows the dose-dependent cytotoxicity of $\mathrm{Cu}(2+)$ ions against macrophages examined. The IC90 concentration was found to be about $100 \mu \mathrm{mol} / \mathrm{L} \mathrm{Cu}(2+)$ ions. Cell viabilities of the macrophages exposed to $\mathrm{Cu}$ (2+) ions with concentrations of less than $100 \mu \mathrm{mol} / \mathrm{L} \mathrm{Cu}$ $(2+)$ ions were not statistically significantly different $(p>0.01)$ from those of control macrophages cultured in the medium without $\mathrm{Cu}(2+)$ ions. In other words, this IC90 concentration of $\mathrm{Cu}(2+)$ ions lay in the sub-cytotoxic region.

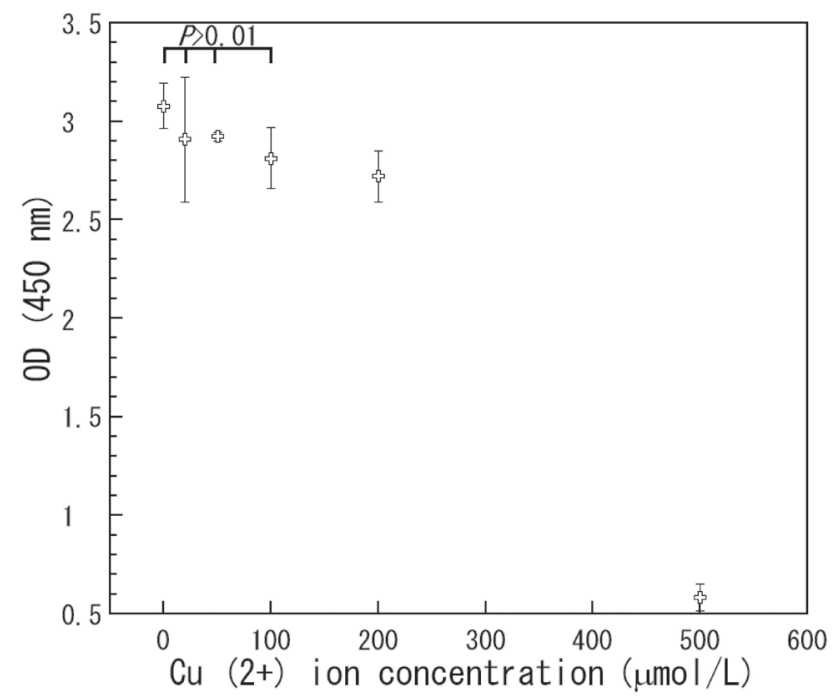

Fig. 2 Effects of $\mathrm{Cu}(2+)$ ion concentrations on cell viability of human macrophages (PMAdifferentiated THP-1 cells) cultured for one day.

$\mathrm{kDa} \quad(+) \mathrm{Cu}$

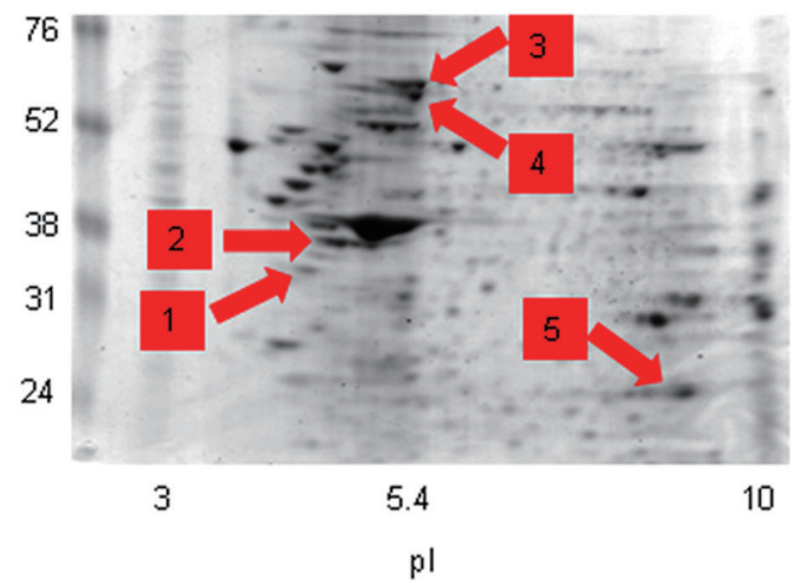

Fig. 3 2D-PAGE of extracts from human macrophages (PMA-diferentiated THP-1 cells): (Left) control cells (coded as Cu $(-))$, (Right) cells exposed to sub-cytotoxic concentration $(100 \mu \mathrm{mol} / \mathrm{L}) \mathrm{Cu}(2+)$ ions for one day (coded as $\mathrm{Cu}(+))$. 


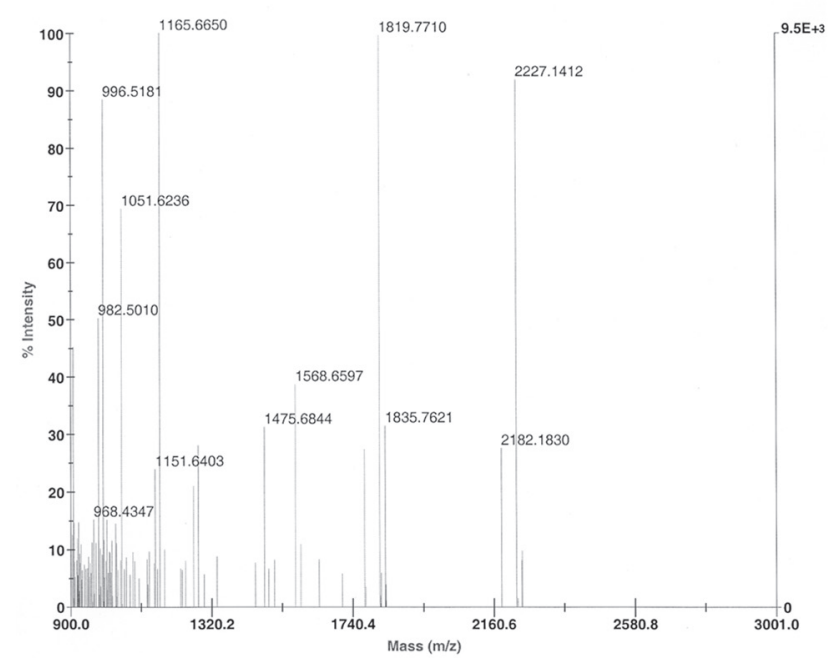

Fig. 4 Mass spectra of protein spot 1 of macrophages exposed to IC90 $(100 \mu \mathrm{mol} / \mathrm{L}) \mathrm{Cu}(2+)$ ions (Fig. 3 (Right)). Note: Mass peaks derived from added CHCA matrix were eliminated from mass finger-print analysis.

The $\mathrm{m} / \mathrm{z}$ values of mass spectra for spot 1 selected for mass finger-print matching were 904.3582, 907.1787, 909.2883, 923.3241, 927.3923, 982.501, 996.5181, 998.4699, 1004.3709, 1007.4778, 1017.5318, 1033.5178, 1035.4429, 1051.6236, 1065.4886, 1082.4700, 1133.6103, 1151.6403, $1154.5071, \quad 1165.6650, \quad 1179.4991, \quad 1211.4879$, 1230.5597, 1265.6576, 1279.6747, 1296.6168, $1334.7549, \quad 1448.7607, \quad 1475.6844, \quad 1488.7319$, $1505.7124, \quad 1568.6597, \quad 1584.8081, \quad 1590.6809$, $1638.7976, \quad 1769.7884, \quad 1774.7767, \quad 1790.812$, $1818.7959, \quad 1819.7710, \quad 1835.7621, \quad 1851.8433$, $1873.8348, \quad 1940.8551, \quad 1993.9435, \quad 2092.9914$, $2099.9604, \quad 2144.9661, \quad 2182.1830, \quad 2185.0821$, 2226.0880, 2227.1412, 2239.0532, 2243.0944, 2408.0742 and 2807.1858.

Proteome analyses of macrophages exposed to IC90 concentration $\mathrm{Cu}(2+)$ ions

Fig. 3 indicates 2D-PAGE of extracts from human macrophage (PMA-differentiated THP-1 cells); (Left) control cells (coded as $\mathrm{Cu}(-))$ and (Right) cells cultured in the medium added with IC90 $(100 \mu \mathrm{mol} / \mathrm{L}) \mathrm{Cu}(2+)$ ions (coded as $\mathrm{Cu}(+)$ ). Detailed comparisons between $\mathrm{Cu}$ $(-)$ and $\mathrm{Cu}(+)$ revealed that five protein spots were significantly increased in $\mathrm{Cu}(+)$. Table 1 shows fold changes of five protein spots, defined by optical densities of test macrophage exposed to IC90 $(100 \mu \mathrm{mol} / \mathrm{L}) \mathrm{Cu}(2+)$ ions for one day (coded as $\mathrm{Cu}(+))$, divided by those of control macrophages (coded as $\mathrm{Cu}(-))$.

Figs. 4, 5, 6, 7 and 8 show mass spectra of protein spots 1, 2, 3, 4 and 5 of $\mathrm{Cu}(+)$ in Fig. 3, respectively. The $\mathrm{m} / \mathrm{z}$ values of mass spectra for each spot selected for mass finger-print matching are displayed in each figure captions. Table 2 summarizes Mascot search (peptide finger-print identification) results of protein name, entry

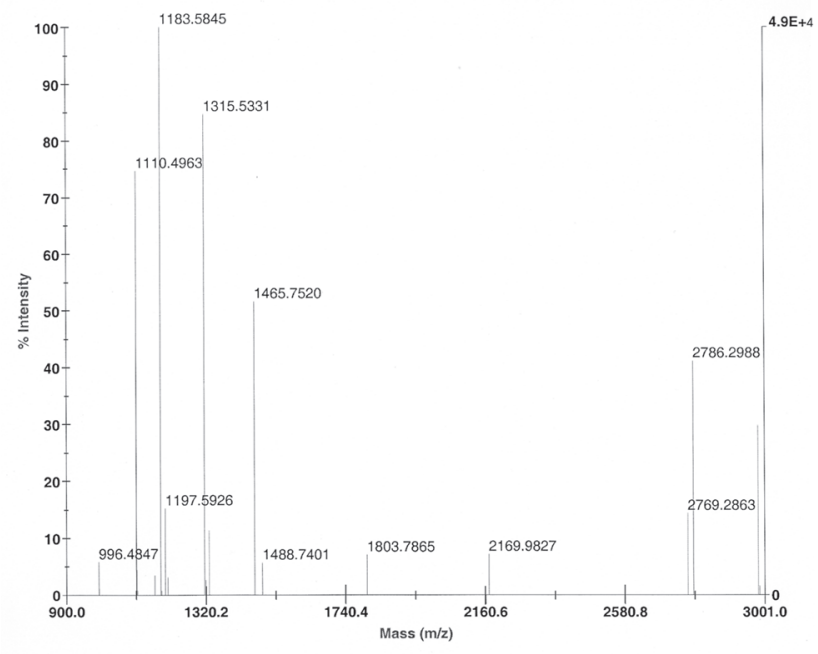

Fig. 5 Mass spectra of protein spot 2 of macrophages exposed to IC90 $(100 \mu \mathrm{mol} / \mathrm{L}) \mathrm{Cu}(2+)$ ions (Fig. 3 (Right)).

The $\mathrm{m} / \mathrm{z}$ values of mass spectra for spot 2 selected for mass finger-print matching were 996.4847, $1051.5910, \quad 1109.5084,1110.4963,1111.4928$, 1165.6237, 1183.5845, 1197.5926, 1205.5447, $1315.5331, \quad 1329.5828, \quad 1465.7520,1488.7401$, 1542.6892, 1803.7865, 2169.9827, 2531.2580, 2662.1643, 2769.2863, 2786.2988, 2807.2917 and 2981.4147 .

name and expectation values $(p)$ for each protein spot. The identifications revealed that four protein spots (spots 2, 3, 4 and 5) were attributed to heat shock protein $70 \mathrm{kDa} 1 \mathrm{~A} / 1 \mathrm{~B}$ while protein spot 1 arose from U5 small nuclear ribonucleoprotein $200 \mathrm{kDa}$ helicase. Identifications of spots 3,4 and 5 were very reliable due to very low expectation values $(p<0.01)$, while those of spots 1 and 2 were less trustable because of relatively large expectation values.

Quantitative real-time PCR analyses of macrophages exposed to IC90 concentration $\mathrm{Cu}(2+)$ ions

Fig. 9 shows relative quantities (RQ) of GAPDH, HSPA1A and HSPA1B mRNAs of control macrophage (coded as $\mathrm{Cu}(-)$ ), and test macrophage exposed to IC90 $\mathrm{Cu}(2+)$ ions for 1 day (coded as $\mathrm{Cu}(+)$ ). Both RQs of HSPA1A and HSPA1B mRNA of the latter test macrophage $(\mathrm{Cu}(+))$ were significantly greater than those of control macrophage $(\mathrm{Cu}(-))$, respectively $(p<0.01)$.

\section{DISCUSSION}

Eluted metallic ions from dental noble alloys might be not only $\mathrm{Cu}$ ions, but also $\mathrm{Au}, \mathrm{Ag}$, and $\mathrm{Zn}$ ions ${ }^{2)}$. Although the effects of all these metallic ions on macrophage must be considered in the future, the effects of $\mathrm{Cu}$ ions on macrophage was considered in this study as a first step. 


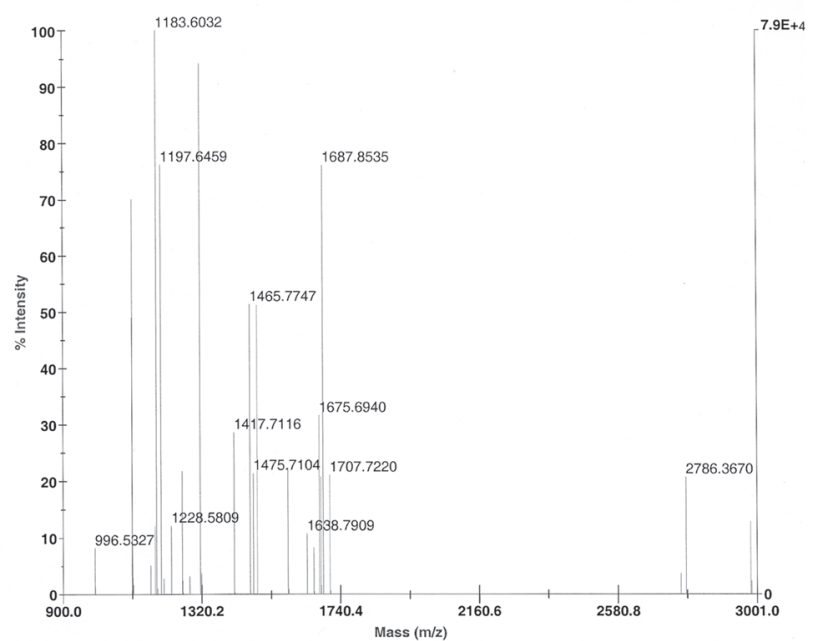

Fig. 6 Mass spectra of protein spot 3 of macrophages exposed to IC90 $(100 \mu \mathrm{mol} / \mathrm{L}) \mathrm{Cu}(2+)$ ions (Fig. 3 (Right)).

The $\mathrm{m} / \mathrm{z}$ values of mass spectra for spot 3 selected for mass finger-print matching were 996.5327, $1109.5240, \quad 1110.5167, \quad 1165.6663, \quad 1179.5595$, $1183.6032, \quad 1197.6459, \quad 1205.5779, \quad 1228.5809$, $1261.6070, \quad 1283.5864, \quad 1299.5813, \quad 1315.5581$, $1318.5960, \quad 1405.7230, \quad 1417.7116, \quad 1465.7747$, $1474.7286, \quad 1475.7104, \quad 1487.6643, \quad 1493.7085$, $1580.7641, \quad 1614.7512, \quad 1638.7909, \quad 1658.8061$, $1675.6940, \quad 1680.7949, \quad 1687.8535, \quad 1707.7220$, 1803.8104, 1838.8772, 1993.9145, 2169.0227, 2265.1318, 2769.3006, 2786.3670 and 2981.4869.

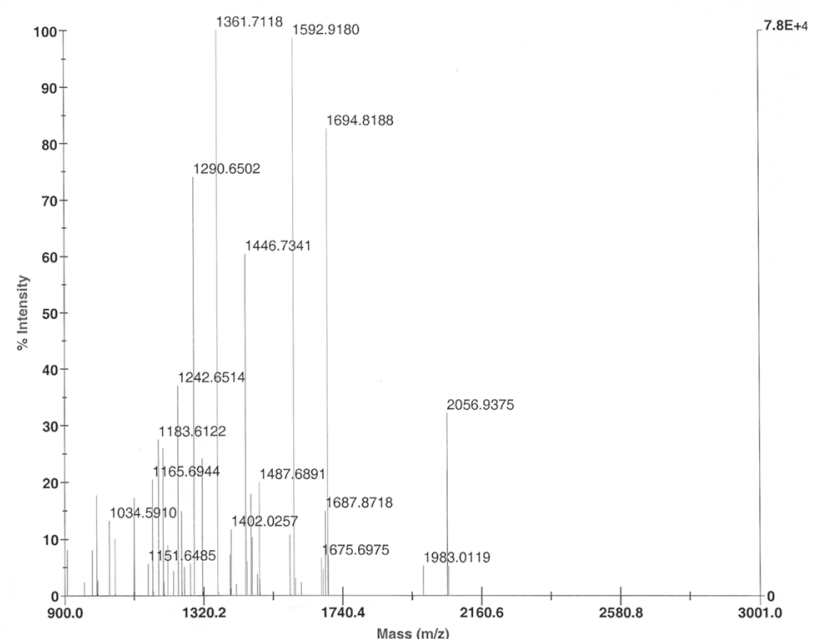

Fig. 7 Mass spectra of protein spot 4 of macrophages exposed to IC90 $(100 \mu \mathrm{mol} / \mathrm{L}) \mathrm{Cu}(2+)$ ions (Fig. 3 (Right)).

The $\mathrm{m} / \mathrm{z}$ values of mass spectra for spot 4 selected for mass finger-print matching were 907.2047, 982.5189, 996.5497, 1034.5910, 1051.6610, $1109.5380, \quad 1110.5204,1151.6485, \quad 1165.6944$, $1183.6122, \quad 1197.6455, \quad 1211.6398, \quad 1228.5922$, $1242.6514, \quad 1253.5913, \quad 1261.6097, \quad 1279.7022$, $1290.6502, \quad 1315.5772, \quad 1361.7118, \quad 1398.7346$ $1402.0257, \quad 1446.7341, \quad 1450.7233,1462.7318$, $1465.7520, \quad 1481.7668, \quad 1487.6891, \quad 1580.7657$, $1591.8738, \quad 1592.9180, \quad 1596.7673, \quad 1614.8595$, $1675.6975, \quad 1680.7890, \quad 1687.8718, \quad 1694.8188$, $1696.8074, \quad 1716.7987, \quad 1856.8930, \quad 1981.9920$, 1983.0119, 2055.9442, 2056.9375, 2142.0642, 2169.04389, 2309.2387 and 2786.3794.

Table 1 Fold change of five protein spots, defined by optical densities of test macrophage exposed to IC90 (100 $\mu$ mol/L) $\mathrm{Cu}(2+)$ ions for one day (coded as $\mathrm{Cu}(+))$, divided by those of control macrophages (coded as $\mathrm{Cu}(-))$, expressed as mean values $(n=2)$.

\begin{tabular}{lccc}
\hline Spot number & First measurement & Second measurement & Average \\
\hline 1 & 5.86 times & 8.84 times & 7.35 times \\
2 & 1.27 times & 3.17 times & 2.22 times \\
3 & 5.27 times & 6.13 times & 5.70 times \\
4 & 2.81 times & 2.90 times & 2.86 times \\
5 & 5.06 times & 3.16 times & 4.11 times \\
\hline
\end{tabular}

Table 2 Mascot peptide mass finger-print identifications of five up-regulated protein spots of macrophages exposed to IC90 $\mathrm{Cu}(2+)$ ions.

\begin{tabular}{lllc}
\hline Spot number & \multicolumn{1}{c}{ Protein name } & Entry name & Expectation values $(p)$ \\
\hline 1 & U5 small nuclear ribonucleoprotein $200 \mathrm{kDa}$ helicase & U520_Human & 0.01 \\
2 & Heat shock $70 \mathrm{kDa}$ protein 1A/1B & HSP71_Human & 0.091 \\
3 & Heat shock $70 \mathrm{kDa}$ protein 1A/1B & HSP71_Human & $6.4 \mathrm{e}^{-11}$ \\
4 & Heat shock $70 \mathrm{kDa}$ protein 1A/1B & HSP71_Human & $3.2 \mathrm{e}^{-07}$ \\
5 & Heat shock $70 \mathrm{kDa}$ protein 1A/1B & HSP71_Human & $7.0 \mathrm{e}^{-05}$ \\
\hline
\end{tabular}




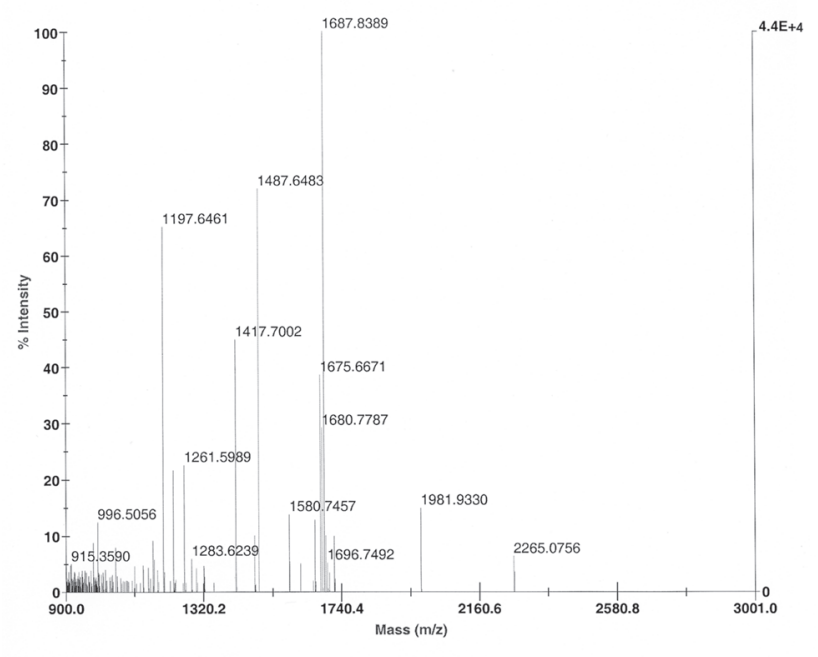

Fig. 8 Mass spectra of protein spot 5 of macrophages exposed to IC90 $(100 \mu \mathrm{mol} / \mathrm{L}) \mathrm{Cu}(2+)$ ions (Fig. 3 (Right)).

The $\mathrm{m} / \mathrm{z}$ values of mass spectra for spot 5 selected for mass finger-print matching were 915.3590, 948.3692, 982.4706, 996.5056, 1051.5835, $1053.485554,1109.4336,1136.5066,1151.5244$, $1165.6711, \quad 1169.5261, \quad 1197.6461, \quad 1200.6062$, $1228.5689, \quad 1235.5415, \quad 1261.5989, \quad 1283.6239$, $1321.5961, \quad 1417.7002,1474.72920,1487.6483$, $1580.7457, \quad 1581.76013,1614.7609, \quad 1658.7681$, $1675.6671, \quad 1680.7787, \quad 1687.8389, \quad 1691.7111$, 1696.7492, 1702.7568, 1717.7844, 1981.9330, 2093.0140, 2264.0484 and 2265.0756.

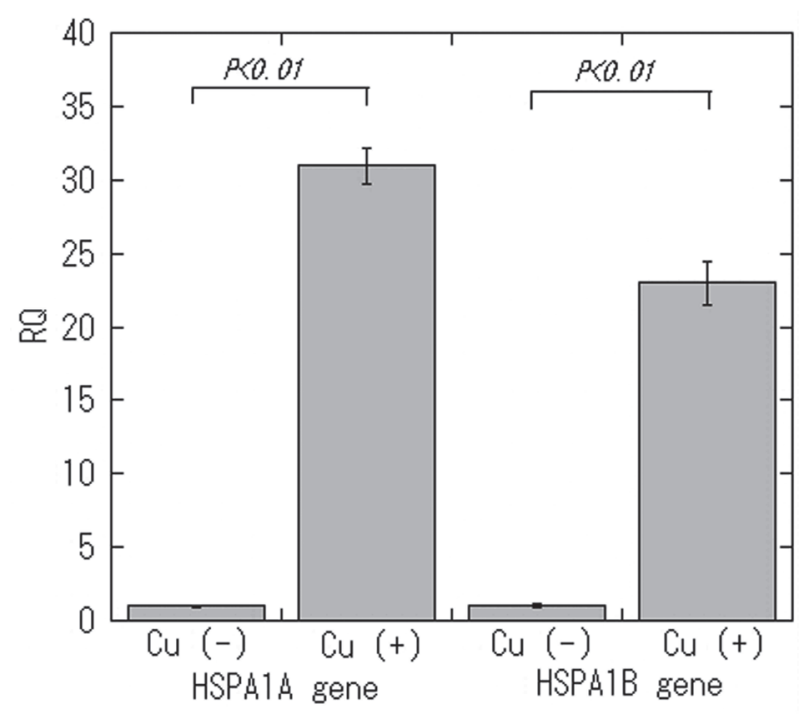

Fig. 9 Relative quantities (RQ) of HSPA1A and HSPA1B mRNAs of control macrophage (coded as $\mathrm{Cu}(-)$ ), and test macrophage exposed to IC90 $\mathrm{Cu}(2+)$ ions for 1 day (coded as $\mathrm{Cu}(+)$ ). Note: RQ values of $\mathrm{Cu}$ $(-)$ and $\mathrm{Cu}(+)$ were calibrated against GAPDH mRNAs of each cells.
In dental materials community, the effects of $\mathrm{Cu}(2+)$ ions on human cells have been evaluated simply by measuring cell proliferation (i.e. cell viabilities) ${ }^{7}$, and the underlying mechanisms have not been well investigated. Only recently, cell death due to high concentration $\mathrm{Cu}(2+)$ ions was evaluated by oxidative stress and its induced apoptosis ${ }^{18)}$. The effects of low dose $\mathrm{Cu}(2+)$ ions on macrophages have not been well investigated $^{8)}$, and related studies had been highly anticipated.

Proteome analysis consisting of 2D electrophoresis and MALDI-TOF mass spectroscopy has recently been used to clinically diagnose dental patients (e.g. those suffering from Sjögren's syndrome ${ }^{19)}$ ), but its availability in dentistry is limited due to high cost and laborious handling. Proteome analysis was conducted in this study, because it was expected to unveil new biological phenomenon in the macrophage exposed to low-cytotoxic IC90 $\mathrm{Cu}(2+)$ ions at protein expression levels.

By proteome analysis, we confirmed that expression of one protein, heat shock $70 \mathrm{kDa}$ protein 1A/1B (HSP70) was specifically up-regulated in the macrophage when exposed to IC90 Cu (2+) ions (Table 2). Identified HSP70 had four distinctive protein spots (protein spots 2, 3, 4 and 5). Such separation in one protein is not strange in MALDI-TOF mass spectroscopy because HSP70 could be partially degraded during the sample preparation, leading to production of separated protein spots. Since original HSP70 has an isoelectric point $(\mathrm{pI})$ value of 5.5 and a protein molecular weight of $70053 \mathrm{Da}^{20)}$, either one of protein spots 3 and 4 in Fig. 3 might be native HSP70. Identification of other one protein (protein spot 1) must only be treated as one possible choice with less reliability because of its high expectation value (Table 2).

The increase in the expression of HSP70 protein appeared to reflect the self-protection activities of macrophages against intracellularly invading $\mathrm{Cu}(2+)$ ions which damage proteins by unfolding and crosslinking. Heat shock proteins function as intra-cellular chaperones for other proteins ${ }^{21)}$. They play an important role in protein-protein interactions such as folding and assisting in the establishment of proper protein conformation (shape) and prevention of unwanted protein aggregation $^{21)}$.

The increased HSP70 expression of the macrophage due to IC90 $\mathrm{Cu}(2+)$ ions was successfully confirmed by expressions of HSPA1A and HSPA1B mRNAs (Fig. 9). The HSP expression is encoded by expressions of HSPA1A and HSPA1B mRNAs ${ }^{22)}$. The up-regulation of HSP70 mRNA due to $\mathrm{Cu}(2+)$ ions has already been reported as a biomarker of cytotoxicity of metal ions against HeLa S3 cells by Hashimoto et al. ${ }^{23)}$. We verified this up-regulation at the protein expression levels of human macrophages.

Finally, it might be worth to speculate reasons why IC90 $\mathrm{Cu}(2+)$ ions increased HSP70 of the macrophage at protein levels. Two sides are considered here. (1) Human cells have a unique transport system of $\mathrm{Cu}(2+)$ ions $\left.{ }^{9}\right)$ from extracellular region to intracellular one; and intracellularly liberated $\mathrm{Cu}(2+)$ ions can bind to, un-fold 
and cross-link intracellular proteins. The resultant proteins might lose their proper function and be recognized as damaged ones. (2) In any human cell, $\mathrm{H}_{2} \mathrm{O}_{2}$ is routinely formed when super-oxide $\left(\mathrm{O}_{2}^{-}\right)$from mitochondria is reduced. If excess $\mathrm{Cu}(2+)$ ions exist adjacent to $\mathrm{H}_{2} \mathrm{O}_{2}, \mathrm{OH}^{-}$radicals are formed by Fenton's reaction, which damage not only proteins but also lipids as oxidative stress ${ }^{11)}$. For both (1) and (2) cases, HSP70 might play important roles to restore or eliminate intracellular proteins damaged by $\mathrm{Cu}(2+)$ ions of the macrophage as protective measures ${ }^{21}$.

\section{CONCLUSIONS}

We found that macrophages cultured for one day in IC90 $(100 \mu \mathrm{mol} / \mathrm{L}) \mathrm{Cu}(2+)$ ions specifically increased one protein, namely heat shock $70 \mathrm{kDa}$ protein $1 \mathrm{~A} / 1 \mathrm{~B}$ (HSP70). The up-regulation of HSP70 expression was confirmed by expressions of corresponding HSPA1A and HSPA1B mRNAs.

It appeared that a proteome analysis might be useful for the cytotoxic evaluation of low concentration other metallic ions except $\mathrm{Cu}$ ions contained in dental alloys in the future.

\section{ACKNOWLEDGMENTS}

This study was supported in part by $(1,2)$ Grant-in-Aids for (B) 21390526 and (Young Scientists B) 21791830 by Japan Society for the Promotion of Science; and $(3,4)$ Grant-in-Aids for the Open Research Project from 2007 to 2011 and for Strategic Medical Science Research Center from 2010 to 2014 from Ministry of Education, Culture, Sports, Science and Technology, Japan.

\section{REFERENCES}

1) Eick JD, Caul HJ, Hegdahl T, Dickson G. Chemical composition of dental gold casting alloy and dental wrought gold alloys. J Dent Res 1969; 48: 1284-1289.

2) Johansson BI, Lucas LC, Lemons JE. Corrosion of copper, nickel, and gold dental casting alloys: an in vitro and in vivo study. J Biomed Mater Res 1989; 23 (A3 Suppl): 349-361.

3) Ayad MF, Vermilyea SG, Rosenstiel SF. Corrosion behavior of as-received and previously cast high noble alloy. J Prosthet Dent 2008; 100: 34-40.

4) Hidaka S, Okamoto Y, Abe K. Elutions of metal ions from dental casting alloys and their effect on calcium phosphate precipitation and transformation. J Biomed Mater Res 1994; 28: $175-180$

5) Issa Y, Brunton P, Waters CM, Watts DC. Cytotoxicity of metal ions to human oligodendroglial cells and human gingival fibroblasts assessed by mitochondrial dehydrogenase activity. Dent Mater 2008; 24: 281-287.

6) Fuhrman B, Shiner M, Volkova N, Aviram M. Cell-induced copper ion-mediated low density lipoprotein oxidation increases during in vivo monocyte-to-macrophage differentiation. Free Radic Biol Med 2004; 37: 259-271.

7) Wataha JC, Lockwood PE, Schedle A. Effect of silver, copper, mercury, and nickel ions on cellular proliferation during extended, low-dose exposures. J Biomed Mater Res 2000; 52: 360-364.

8) Videla LA, Fernández V, Tapia G, Varela P. Oxidative stressmediated hepatotoxicity of iron and copper: role of Kupffer cells. Biometals 2003; 16: 103-111.

9) Kaplan JH, Lutsenko S. Copper transport in mammalian cells: special care for a metal with special needs. J Biol Chem 2009; 284: 25461-25465.

10) Salehifar E, Shokrzadeh M, Ghaemian A, Aliakbari S, Saeedi Saravi SS. The study of $\mathrm{Cu}$ and $\mathrm{Zn}$ serum levels in idiopathic dilated cardiomyopathy (IDCMP) patients and its comparison with healthy volunteers. Biol Trace Elem Res 2008; 125: 97-108.

11) Hureau C, Faller P. Abeta-mediated ROS production by $\mathrm{Cu}$ ions: structural insights, mechanisms and relevance to Alzheimer's disease. Biochimie 2009; 91: 1212-1217.

12) Rana SV. Metals and apoptosis: recent developments. J Trace Elem Med Biol 2008; 22: 262-284.

13) Raap U, Stiesch M, Reh H, Kapp A, Werfel T. Investigation of contact allergy to dental metals in 206 patients. Contact Dermatitis 2009; 60: 339-343.

14) Park JY, Mun JH, Lee BH, Heo SH, Kim GH, Yoo HW. Proteomic analysis of sera of asymptomatic, early-stage patients with Wilson's disease. Proteomics Clin Appl 2009; 3: 1185-1190.

15) Taira M, Kagiya $T$, Harada $H$, Sasaki M, Kimura $S$, Narushima T, Nezu T, Araki Y. Microscopic observations and inflammatory cytokine productions of human macrophage phagocytising submicron titanium particles. J Mater Sci Mater Med 2010; 21: 267-275.

16) Taira M, Nezu T, Sasaki M, Kimura S, Kagiya T, Harada H, Narushima T, Araki Y. Gene expression analyses of human macrophage phagocytizing sub-micron titanium particles by allergy DNA chip $\left(\right.$ Genopal $\left.^{\mathrm{TM}}\right)$. Biomed Mater Eng 2009; 19: 63-70.

17) Ohara-Nemoto $Y$, Ono $T$, Shimoyama $Y$, Kimura S, Nemoto TK. Homologous and heterologous expression and maturation processing of extracellular glutamyl endopeptidase of Staphylococcus epidermidis. Biol Chem 2008; 389: 1209-1217.

18) Pang JH, Chau LY. Copper-induced apoptosis and immediate early gene expression in macrophages. Atherosclerosis 1999; 146: 45-52.

19) Fleissig Y, Deutsch O, Reichenberg E, Redlich M, Zaks B, Palmon A, Aframian DJ. Different proteomic protein patterns in saliva of Sjögren's syndrome patients. Oral Dis 2009; 15: 61-68.

20) Zierhut B, Mechtler K, Gartner W, Daneva T, Base W, Weissel M, Niederle B, Wagner L. Heat shock protein 70 (Hsp70) subtype expression in neuroendocrine tissue and identification of a neuroendocrine tumour-specific Hsp70 truncation. Endocr Relat Cancer 2004; 11: 377-389.

21) Pratt WB, Morishima Y, Peng HM, Osawa Y. Proposal for a role of the Hsp90/Hsp70-based chaperone machinery in making triage decisions when proteins undergo oxidative and toxic damage. Exp Biol Med (Maywood) 2010; 235: 278-289.

22) Singh R, Kølvraa S, Bross P, Christensen K, Bathum L, Gregersen N, Tan Q, Rattan SI. Anti-inflammatory heat shock protein 70 genes are positively associated with human survival. Curr Pharm Des 2010; 16: 796-801.

23) Hashimoto Y, Ueda A, Nakamura M. Evidence that HSP70 gene expression may be useful for assessing the cytocompatibility of dental biomaterials. Dent Mater J 2004; 23: 184-189. 